\title{
Evaluation of selected minerals in the blood of crossbred pigs fed toasted soybean hull
}

Ogunbode, A. A., Mustapha, T. B., Adams, T. O., Stephen, F. T. and Amusat, W. A. Department of Animal Production Technology, Faculty of Animal and Fisheries Technology,

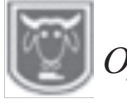

Oyo State College of Agriculture and Technology, P.M.B.10, Igboora, Nigeria

Corresponding author: aaogunbode@gmail.com; +2348062455318

\section{Abstract}

The significance of the mineral elements in animal nutrition cannot be over emphasized. The presence of mineral elements in animal feed is vital for adequate the metabolic processes. Sixteen (16) crossbred weaned pigs aged eight weeks weighing between 6-7 kg were used in experiment to investigate the effect of feeding varying dietary levels of toasted soybean hull on macro and micro minerals in blood of weaned pigs. The pigs were randomly allotted to four treatments T1, T2, T3 and T4 containing $0 \%, 5 \%, 10 \%$ and $15 \%$ of toasted soybean hull respectively. Water was supplied ad libitum. At the end of feeding trial, two pigs per treatment were selected and blood collected for analysis. Results showed that there were significant $(p>0.05)$ differences in macro minerals. Calcium value ranged from $10.40 \mathrm{mg} / \mathrm{dL}$ in T1 to $11.05 \mathrm{mg} / \mathrm{dL}$ in T4. Phosphorus ranged from $13.20 \mathrm{mg} / \mathrm{dL}$ to $17.54 \mathrm{mg} / \mathrm{dL}$. Potassium value ranged from $4.65 \mathrm{mg} / \mathrm{dL}$ to $5.65 \mathrm{mg} / \mathrm{dL}$. Magnesium ranged from $(3.98 \mathrm{mg} / \mathrm{dL}$ to $4.80 \mathrm{mg} / \mathrm{dL})$. Sodium value ranged from $(137.50 \mathrm{mg} / \mathrm{dL}$ to $143.50 \mathrm{mg} / \mathrm{dL})$. Iron, copper and manganese values were significantly $(p<0.05)$ influenced by the dietary treatments with the values ranging from $57.50-48.00 \mathrm{mg} / \mathrm{kg}, 42.34-31.87 \mathrm{mg} / \mathrm{kg}$ and $10.95-8.85 \mathrm{mg} / \mathrm{kg}$ respectively. For zinc, the value ranged from $1.04 \mathrm{mg} / \mathrm{kg}$ to $1.30 \mathrm{mg} / \mathrm{kg}$. Based on the findings of this study, it can be concluded that toasted soybean hull could be fed to weaned pigs up to $15 \%$ inclusion level without any adverse effects on the macro and micro minerals composition of weaned pigs.

Keywords: blood, macro and micro minerals, soybean hull, toasting, weaned pigs

\section{L'Évaluation de certains minéraux dans le sang des porcs croisés nourris à la coque de soja grillée}

\section{Résumé}

On ne saurait trop insister sur l'importance des éléments minéraux dans la nutrition animale. La présence d'éléments minéraux dans l'alimentation animale est essentielle pour un traitement métabolique adéquat. Seize (16) porcs sevrés croisés âgés de huit semaines pesant entre 6 et $7 \mathrm{~kg}$ ont été utilisés dans l'expérience pour étudier l'effet de l'alimentation de différents niveaux alimentaires de coque de soja grillé sur les macro et micro minéraux dans le sang des porcs sevrés. Les porcs ont été attribués au hasard à quatre traitements T1, T2, T3 et $T 4$ contenant respectivement $0 \%, 5 \%, 10 \%$ et $15 \%$ de la coque de soja grillée. L'eau a été fournie ad libitum. À la fin de l'essai d'alimentation, deux porcs par traitement ont été sélectionnés et le sang prélevé pour analyse. Les résultats ont montré qu'il y avait des différences significatives ( $p>0,05)$ dans les minéraux macro. La valeur de calcium s'est étendue de $10.40 \mathrm{mg} / \mathrm{dL}$ dans T1 à11.05mg/dL dans T4. Le phosphore tégrait de 13,20 $\mathrm{mg} / \mathrm{dl}$ à $17,54 \mathrm{mg} / \mathrm{dl}$. La valeur de potassium s'est étendue de $4.65 \mathrm{mg} / \mathrm{dL}$ à $5.65 \mathrm{mg} / \mathrm{dL}$. Le magnésium tégrait de $(3,98 \mathrm{mg} / \mathrm{dL}$ à $4,80 \mathrm{mg} / \mathrm{dL})$. La valeur en sodium varierait de $(137,50$ $\mathrm{mg} / \mathrm{dL}$ à $143,50 \mathrm{mg} / \mathrm{dL}$ ). Les valeurs de fer, de cuivre et de manganèse ont été 


\section{Evaluation of selected minerals in the blood of crossbred pigs fed toasted soybean hull}

significativement influencées $(p<0,05)$ par les traitements diététiques dont les valeurs vont de 57,50-48,00 mg/kg, 42,34-31,87 mg/kg et 10,95-8,85 mg/kg respectivement. Pour le zinc, la valeur varierait de $1,04 \mathrm{mg} / \mathrm{kg}$ à $1,30 \mathrm{mg} / \mathrm{kg}$. D'après les résultats de cette étude, on peut conclure que la coque de soja grillée pourrait être nourrie à des porcs sevrés jusqu'à un niveau d'inclusion de $15 \%$ sans effets négatifs sur la composition macro et micro-minérale des porcs sevrés.

Mots-clés: sang, macro et micro minéraux, coque de soja, grillage, porcs sevrés

\section{Introduction}

The role of minerals in animal production is an area of strong interest for producers, feed manufacturers, veterinarians and scientists. Minerals constitute a small percentage of pig diets, but their importance to growth, health and productivity of the pig cannot be over emphasized. They have a role in digestion, metabolism of protein, fats and carbohydrates and the structure of chromosomes, enzymes, nerves, blood, skeleton, hair and milk(Fakler et al., 2004). The efficiency of mineral absorption depends on concentration of that mineral in the diet, the mineral source and its availability, mineral to mineral interactions in the diet and the mineral status of the animal. Most pigs are housed in pens under confinement and they depend solely on their daily feed to supply needed mineral requirements. Excessive use of minerals can lead to serious consequences such as antagonistic interactions between minerals leading to potential deficiencies and impaired growth of the pig (Olaiya, 2006). Macro minerals are the minerals that pig require in larger quantities usually described for inclusion in percent of the diet. Adequate trace mineral intake and absorption is required for a variety of metabolic functions including immune response to pathogenic challenge, reproduction and growth. Mineral supplementation strategies quickly become complex because trace mineral status is critical in order to obtain optimum performance in modern animal production system (Simsek and Aykut, 2007). Zinc is essential to a wide variety of processes, including the synthesis of collagen and keratin. It is also important to the development and function of the pig's immune system. Zinc deficiencies can lead to bone abnormalities, decreased tissue strength and decreased immune function (Ajay, 2015). Copper is a necessary component for tissue formation and supports skin, bone, tendon and intestinal strength, through its function in enzymes responsible for cross linking collagen and keratin tissue. Deficiencies in copper can cause weak bones and increased bone breakage (Ajay, 2015). Manganese is essential for bone development as it is required for forming the proteoglycan matrix in which collagen and elastin are embedded within the bone. As animal trace mineral status declines immunity and enzyme functions are compromised first, followed by a reduction in maximum growth and fertility and finally normal growth and fertility decrease prior to evidence of clinical deficiency. Dietary trace minerals may be added to swine diets as inorganic or organic forms (Fakler et al., 2004). Minerals are inorganic substances present in all body tissues and fluids and their presence is necessary for the maintenance of certain physicochemical processes which are essential to life (Eruvbetine, 2003). Macro and micro minerals deficiencies constitute significant nutritional and public health problems. Every form of life requires these inorganic elements for normal life processes (Ozcan, 2003). The micro minerals are required in amounts less than $100 \mathrm{mg} \backslash \mathrm{dL}$ while the macro minerals are required in amount 
greater than $100 \mathrm{mg} / \mathrm{dL}$ (Murray et al., 2000). Dietary deficiencies due to absence of these vital nutrients in feedstuff are observed to have significant adverse effects on animals consuming the feedstuff. Both micro and macronutrients deficiencies are known to impair the body functions and to elevate the severity of many diseases and infections in man and animals while compromising growth, development and reducing productivity in animals. This paper was aimed at evaluating the minerals constituents in the blood of crossbred weaned pigs fed toasted soybean hull based diets.

\section{Materials and methods Experimental site}

The experiment was carried out at the piggery unit of the Teaching and Research Farm of the Oyo State College of Agriculture and Technology, Igboora, Nigeria. The research was conducted from May, 2018 to July, 2018.The experimental site lies within the in savannah forest zone on latitude $7^{0} 43 \mathrm{~N}$ and longitude $3^{\circ} 28 \mathrm{E}$ in an elevation of $140 \mathrm{~m}$ above sea level. The average minimum temperature is above $21.5^{\circ} \mathrm{C}$ and maximum average temperature is about $32.5^{\circ} \mathrm{C}$ (Google Earth 2018).

\section{Experimental diet}

The soybean hull was procured from Karma Nigeria Limited Ibadan, Oyo state, Nigeria and was toasted over fire at $70^{\circ} \mathrm{C}$ for 30 minutes. The toasting involved adding about $5 \mathrm{~kg}$ soybean hull in to an open cast iron pan already set over a fire. The soybean hull was stirred to prevent it from sticking to pan and from burning until it turned brownish and produced sweet smelling aromatic flavor.

Experimental animals and management

Sixteen (16) crossbred (Largewhite X
Landrace) weaned pigs in their $8^{\text {th }}$ weeks of age were purchase from a reputable commercial pig farm in Ibadan with the assistance of veterinarian to ascertain their health status. The pigs were dewormed to eliminate endo and ectoparasites. The pig was fed $4 \%$ of their body weight as feed per day at the beginning of the experiment and increase as the animals were advancing in age while water was supplied ad libitum.

\section{Blood collection for mineral analysis}

At the end of eight weeks of feeding trial, $5 \mathrm{~mL}$ of blood from two pigs per treatment was collected through the ear vein with the use of syringe and needle into plain bottles for the determination of macro and micro minerals. Calcium and magnesium were determined using Atomic Absorption Spectrophotometer (Buck Scientific Model 210 VGP), while sodium and potassium were determined using Flame Photometer. Micro minerals elements analysis was carried out using atomic absorption spectrophotometer Hitachi Model 180 - 50 equipped with background correction and a data processor. All the parameters were set according to the manufacturers instruction. Iron, zinc and manganese hollow - cathode lamps (made by Mtiorika company) were operated at lamps current was set at 9.5. The flow rate of acetylene for fuel $0.3,0.2$ and $0.2 \mathrm{~kg} / \mathrm{cm}^{2}$ and an air flow rate $1.60 \mathrm{~kg} / \mathrm{cm}^{2}$ was used for Fe, $\mathrm{Zn}$ and $\mathrm{Mn}$ respectively to obtain a clear yellow flame. Sample digested with the $\mathrm{HNO} 3,30 \% \mathrm{H} 2 \mathrm{O} 2$, (2:1) (Kazi et al., 1999).

\section{Statistical analysis}

Data collected was subjected to One - way analysis of variance SAS (2010) and treatment means were separated using Duncan's Multiple Range Test at 5\% level of probability (Steel and Torrie 1980). 
Table 1: The effect of toasted soybean hull on macro and micro minerals

\begin{tabular}{llllll}
\hline & $\mathrm{T} 1$ & $\mathrm{~T} 2$ & $\mathrm{~T} 3$ & $\mathrm{~T} 4$ & SEM \\
\hline Calcium $(\mathrm{mg} / \mathrm{dl})$ & $10.40^{\mathrm{c}}$ & $11.05^{\mathrm{b}}$ & $11.40^{\mathrm{a}}$ & $11.05^{\mathrm{b}}$ & 0.18 \\
Phosphorus $(\mathrm{mg} / \mathrm{dl})$ & $13.20^{\mathrm{c}}$ & $17.54^{\mathrm{a}}$ & $11.98^{\mathrm{d}}$ & $14.98^{\mathrm{b}}$ & 1.04 \\
Sodium $(\mathrm{mg} / \mathrm{dl})$ & $142.50^{\mathrm{a}}$ & $142.00^{\mathrm{a}}$ & $137.50^{\mathrm{a}}$ & $143.50^{\mathrm{a}}$ & 1.15 \\
Potassium $(\mathrm{mg} / \mathrm{dl})$ & $4.65^{\mathrm{b}}$ & $5.50^{\mathrm{a}}$ & $5.00^{\mathrm{b}}$ & $5.65^{\mathrm{a}}$ & 0.19 \\
Magnesium $(\mathrm{mg} / \mathrm{dl})$ & $4.80^{\mathrm{a}}$ & $4.09^{\mathrm{b}}$ & $3.98^{\mathrm{b}}$ & $4.24^{\mathrm{b}}$ & 0.57 \\
Iron $(\mathrm{mg} / \mathrm{kg})$ & $49.50^{\mathrm{c}}$ & $48.00^{\mathrm{d}}$ & $57.50^{\mathrm{a}}$ & $55.00^{\mathrm{b}}$ & 1.94 \\
Zinc $(\mathrm{mg} / \mathrm{kg})$ & $1.12^{\mathrm{a}}$ & $1.22^{\mathrm{a}}$ & $1.04^{\mathrm{a}}$ & $1.30^{\mathrm{a}}$ & 0.05 \\
Copper $(\mathrm{mg} / \mathrm{kg})$ & $31.87^{\mathrm{d}}$ & $39.21^{\mathrm{b}}$ & $42.34^{\mathrm{a}}$ & $37.13^{\mathrm{c}}$ & 1.19 \\
Manganese $(\mathrm{mg} / \mathrm{kg})$ & $10.95^{\mathrm{a}}$ & $8.85^{\mathrm{d}}$ & $9.84^{\mathrm{b}}$ & $9.44^{\mathrm{c}}$ & 0.38 \\
\hline
\end{tabular}

$\mathrm{a}, \mathrm{b}, \mathrm{c}, \mathrm{d}$ Means on the same row with different superscripts differ significantly

\section{Results and discussion}

Results of the selected minerals composition of crossbred weaned pigs fed graded level of toasted soybean hull was presented in Table 1. The highest value $(11.40 \mathrm{mg} / \mathrm{dL})$ of calcium was recorded in pig fed diet 3 while the least value $(10.40 \mathrm{mg} / \mathrm{dL})$ was obtained in pig fed control diet. The values of phosphorus ranged from $(14.98 \mathrm{mg} / \mathrm{dL})$ in diet 4 to $(11.98 \mathrm{mg} / \mathrm{dL})$ in diet 3. Potassium was highest $(5.65 \mathrm{mg} / \mathrm{dL})$ in pig fed diet 4 while the least value $(4.65 \mathrm{mg} / \mathrm{dL})$ was recorded in pigs on control diet. Pig fed control diet had the highest value $(4.80 \mathrm{mg} / \mathrm{dL})$ of magnesium while the least value $(3.98 \mathrm{mg} / \mathrm{dL})$ was obtained in pig fed diet 3 . The differences $(\mathrm{P}<0.05)$ in the mean values for calcium, phosphorus, potassium and magnesium in the experimental animals was due to consumption of toasted soybean hull based diet. This observation was contrary to the findings of Ogunbode et al., (2017) when raw pride of Barbados (Caesalpina pulcherrima) seed meal were fed to crossbred weaned pigs where the test ingredient compares favourably with the control diet. Calcium and phosphorus play an important role in the development and maintenance of the skeletal system, blood clotting, muscle contraction and many other regulatory functions (Crenshaw, 2001). Pigs fed $10 \%$ inclusion levels of processed soybean hull had the highest $(11.40 \mathrm{mg} / \mathrm{dl})$ calcium while the lowest value (10.40mg/dl) were recorded for pigs maintained on the control diet. Phosphorus was highest $(17.54 \mathrm{mg} / \mathrm{dl})$ in pigs fed $5 \%$ of the experimental diets while pigs on $10 \%$ inclusion level of toasted soybean hull recorded the least value $(11.98 \mathrm{mg} / \mathrm{dl})$. This can be attributed to the processing technique employed to detoxifying the toxins in raw soybean hull. Calcium and phosphorus are the two most abundant minerals in the pig. Phosphorus is required in the diet of pigs for proper skeletal growth and mineralization as well as cellular functions. Decrease in serum phosphorous is associated with rickets and hyperparathyroidism. Since phosphorous value is highly significant such disease was not noticed. Potassium is involved in nervemuscle function, electrolyte balance, ammonium ion excretion by the kidney (NRC, 1988), regulation of heart rate and preventing tetany in skeletal muscle (Hendriks and Moughan, 1993). The increase in serum potassium as level of inclusion of toasted soya bean hull increased indicate hypocalcemia and this was in line with the report of (Hays and Swenson, 1985) when raw pride of Barbados seed meal was fed to weaned pigs. The pigs on test ingredient did not compare favourably with those on control diet, this may be as a result of residual toxins in the processed soybean hull that has ability to inhibit the activities of certain digestive enzyme (Durigan 1989). The residual effect 
of toxins in soybean hull might also affect the digestive system and the kidneys of the pigs and so gastrointestinal disorders that impair absorption such as Crohns disease that limit magnesium absorption might have occurred. The experimental diet had significance effect $(\mathrm{p}<0.05)$ on iron, copper and manganese. Pigs fed diet T3 (10\% inclusion levels of toasted soy bean hull) had the highest value $(57.50 \mathrm{mg} / \mathrm{kg})$ of iron while the lowest value $(48.00 \mathrm{mg} / \mathrm{kg})$ were recorded on the pigs fed diet T2 (5\% inclusion level of toasted soybean hull). Iron value was superior (57.50 and $55.00 \mathrm{mg} / \mathrm{kg}$ on diets 3 and 4 respectively) at 5\% protection limit (Galan et al., 2005). Iron is a trace nutrient needed in the body for haemoglobin formation, normal functioning of the central nervous system and in the oxidation of carbohydrates, proteins and fats (Adeyeye and Otokiti, 1999). The level of iron in the blood of weaned pigs fed toasted soy bean hull is an indication that toasted soy bean hull is a good source of this element suitable to maintain the daily balance. Pigs fed on diet T4 $(10 \%$ inclusion level of processed soybean hull) recorded the highest value $(1.30 \mathrm{mg} / \mathrm{kg})$ of zinc while the lowest value $(1.04 \mathrm{mg} / \mathrm{kg})$ were obtained in pigs on diet T3 (10\% inclusion level of toasted soybean hull). The pigs on the control diet compared favourably with those animals on the test ingredient. Elemental zinc prevents and cures parakeratosis in swine and since the experimental diet did not influence the zinc content of the blood, parakeratosis was not noticed. Poor growth, loss of appetite and a bad feed conversion ratio associated with zinc deficiency were not observed as the quantity of zinc available in the test ingredient were able to meet the nutrient requirement of pigs. The values obtained for copper were significantly $(\mathrm{P}<0.05)$ different across the treatments. Copper is an essential trace nutrient necessary for the haematologic and neurologic systems (Tan et al., 2006). Copper is necessary for the growth and formation of bone, helps in the incorporation of iron in haemoglobin, assist in the absorption of iron from the gastrointestinal tract and in the transfer of iron from tissues to the plasma (Murray et al., 2000). Through the promotion of superoxide dismutase, which deactivates free oxygen radicals, copper is also involved in cell protection and thereby in a healthy immune system. There were significant $(\mathrm{P}<0.05)$ differences in the values obtained for manganese in the blood of weaned pigs fed graded level of toasted soy bean hull based diets. Although the values obtained for weaned pigs maintained on processed soya bean hull were inferior to that of the control diets, manganese deficiency in pigs such as lameness, enlarged hock joints and shortened legs were not noticed this might be as a result of the toasting employed in detoxifying the toxins present in the soy bean hull.

\section{Conclusion}

It can be concluded that toasted soybean hull is a good feed resources and processing of soybean hull had no adverse effects on the pig mineral balance except on sodium and zinc. Therefore, it may be useful as unconventional protein feedstuff in nutrition of monogastric animals.

\section{References}

Adeyeye, E. I. and Otokiti, M. K. O. 1999. Proximate composition and some nutritionally valuable minerals of two varieties of capsicum annum (Bell and Cherry pepper). Discovery and Innovation, 11: $75-$ 81. doi:10.4314/dai.vllil.15537

Ajay, B. 2015. High quality trace minerals support improved breeder hen longevity. International Hatchery Practice. Volume 29, Number 7 pg 25.

Crenshaw, T. D. 2001. Calcium, Phosphorus, Vitamin D and 


\section{Evaluation of selected minerals in the blood of crossbred pigs fed toasted soybean hull}

Vitamin $\mathrm{K}$ in swine nutrition. In: Swine Nutrition, second edition. Editted by A. J. Lewis and L.L. Southern. Pp: 297-335.

Durigan, J . F. 1989. Fatores antinutricionais em alimentos. Anais do Simposio Interfase Nutricao Agricultural, P.155 - 225, Piracicaba, Sao Paulo, Brazil.

Eruvbetine, D. 2003. Canine nutrition and health. A paper presented at the seminar organized by Kensington pharmaceuticals Nigeria Limited. Lagos on August 21

Fakler, T. M., Rapp, C. J. and Cheng, T. K. 2004. Optimizing productivity with minerals. International Pig Topics. Volume 19 Number 3 pg: $11-13$.

Galan, P., Viteri, F., Bertrais, S., Czernichow, Sand Faure, $H$. 2005. Serum concentrations of beta carotene, vitamin $\mathrm{C}$ and $\mathrm{E}$, Zinc and Selenium are influenced by sex, age, diet, smoking status, alcohol consumption and corpulence in a general French adult population. European Journal Clinical Nutrition. 59: 1181-1190. doi:10.1038/sj.ejcn.1602230

Google Earth, 2018. US department of state geographer 2006. Maplink Tele Atlas Data SIO, NOAA, US, Navy, NGA, GEBCOC.

Hays, V. W. and Swenson, M. J. 1985. Minerals and Bones. In: Dukes Physiology of Domestic Animals, Tenth Edition Page 449 466

Hendriks, W. H. and Moughan, P. J. 1993. Whole body mineral composition of entire male and female pigs depositing protein at maximal rates. Livestock Prod. Sci. $33: 161-170$. 16. https://doi.org/10.1016/0301-6226 (93) 90247-f
Kazi, S. S. S., Ali, T.G., Kazi and Kazi, G. H. 1999. Biocycling of trace and toxic elements in different vegetables from sludge samples used as agricultural fertilizer. ACGC. Chem. Cumm., 9: 51 - 56. doi:10.3923/ajps.2002.208.209

Murray, R. K., Granner, D. K., Mayes, P. A. and Rodwel, V. W. 2000. Harpers biochemistry $25^{\text {th }}$ edition McGraw-Hill Health Profession Division, USA.

NRC, 1998. Nutrient requirements of swine $10^{\text {th }}$ edition. National Academy Press, Washington, DC

Ogunbode, A. A., Okeniyi, G., Ojo, B. R. and Gbolahan, S. T. 2017. Selected sera macro and micromineral compositions of crossbred weaner pigs fed raw pride of B a rbados (Caesalpina pulcherrima) seedmeal. J. Anim. Prod. Res. 29 (1):56-62. http://journals.napri.gov.ng

Olaiya, C. O. 2006. Effects of three plant bio regulators on some biochemical properties of Lycopersicon esculentum (L) Mill. Ph.D Thesis, Department of Biochemistry, University of Ibadan.

Ozcan, M. 2003. Mineral content of some plants used as condiments in Turkey. Food chemistry 84: 437440

SAS. 2010. SAS users guide. Release 6.12 edition. SAS Institute Inc Cary NC.USA.

Simsek, A. and Aykut, O. 2007. Evaluation of the microelement profile of Turkish hazelnut (Corylus avellana L) varieties for human nutrition and health. Int. J. Food Sci. Nutr. 58: $677 \quad-\quad 688$. https://doi.org/10.1080/09637480 701403202

Steel, R. G. D. and Torrie, J. H. 1980. Principle and Procedures of 
Statistics $\left(2^{\text {nd }}\right.$

edition). New York. McGraw-Hill Book Company, USA.

Tan, J. C., Burns, D. L. and Jones, H. R. 2006. Severe ataxia, myelopathy and peripheral neuropathy due to acquired copper deficiency in a patient with history of gastrectomy. J. Paenteral Nutr. 30: 446 - 450. doi:10.1177/01486071060300054 46.

Received: $12^{\text {th }}$ October, 2020 Accepted: $8^{\text {th }}$ February, 2021 